\title{
Analysis of the Health Level of Rural Banks Based on the Risk Base Bank Rating Method in Gianyar Regency
}

\author{
Ni Made Taman Sari $\#^{1}$, Ni Made Santini*2 ${ }^{2}$, Made Pratiwi Dewi $\#^{2}$ \\ ${ }^{\# 1 \# 2 \# 3}$ Faculty of Economic and Business, Warmadewa University, Denpasar, Bali-Indonesia
}

\begin{abstract}
The health of a bank is in the interest of all related parties, including bank owners and managers, the public using bank services, and bank supervisors. Bank Indonesia assesses the soundness of banks using a method with a risk approach called the Risk Based Bank Rating (RBBR). This study aims to determine the soundness of Rural Banks (BPR) in Gianyar Regency in 2015-2020 using the RBBR method. This method consists of four assessment factors, namely risk profile, GCG, earnings and capital. The results of the study show that there are still several BPRs in Gianyar Regency that have the predicate of being unhealthy or violating the NPL, LDR and ROA ratios in accordance with the provisions of the law. The assessment of the Good Corporate Governance (GCG) factor in this study focused on the compliance function with the implementation of internal audit and external audit on financial statements implemented by banks. The internal audit function has been implemented by banks from 2015 to 2020. External audits were implemented by banks in 2019 and 2020. In 2019, 19 or 76 percent of 25 banks were audited by external auditors, and 6 banks or 24 percent were not audited by external auditors. The results of the Assessment of Capital Ratio with Minimum Capital Adequacy Ratio (KPMM), all BPRs with Very Healthy Predicate with KPMM Ratio greater than 12 percent. In 2019, 19 or 76 percent of 25 banks were audited by external auditors, and 6 banks or 24 percent were not audited by external auditors. The results of the Assessment of Capital Ratio with Minimum Capital Adequacy Ratio (KPMM), all BPRs with Very Healthy Predicate with KPMM Ratio greater than 12 percent. In 2019, 19 or 76 percent of 25 banks were audited by external auditors, and 6 banks or 24 percent were not audited by external auditors. The results of the Assessment of Capital Ratio with Minimum Capital Adequacy Requirement (KPMM), all BPR with Very Healthy Predicate with KPMM Ratio greater than 12 percent.
\end{abstract}

Keywords-BPR Health Level, Risk Profile, Corporate Governance, Earnings and Capital

\section{INTRODUCTION}

Banks are financial institutions that are very important for people who have excess funds and those who lack funds. Banks based on RI Law NO. 10 of 1998 concerning banking explains that "a bank is a business entity that collects funds from the public in the form of savings and distributes them to the public in the form of credit and or other forms in order to improve the standard of living of the community at large". To assess the health of a bank can be seen from various factors. This assessment aims to determine whether the bank is in a healthy, moderately healthy, unhealthy or unhealthy condition. For a bank that is considered healthy or whose health continues to improve, it will not be a problem, because that is what is expected and must be maintained. However, for a continuously unhealthy bank,[1][2].

Based on the Financial Services Authority Regulation No. 4/POJK.03/2016 that banks are required to conduct an individual bank soundness assessment using a risk approach (Risk-Based Bank Rating) which is a comprehensive and structured assessment of performance results with an assessment coverage of factors, namely the Risk Profile. ), Good Corporate Governance (GCG), Earning (Rentability), and Capital (Capital).[3]

There are two types of banks based on RI Law no. 10 of 1998, banks consist of Commercial Banks and Rural Banks (BPR)[4]. Gianyar Regency is an area that has 25 BPRs. However, BPRs in Gianyar Regency are still experiencing credit repayment problems, so that some BPRs cause bad loans, seen from the NPL figure, which far exceeds the limit set by the Financial Services Authority (OJK) of five percent as seen in table 1 below: 
DOI: $\underline{10.51386 / 25815946 / \mathrm{ijsms}-\mathrm{v} 4 \mathrm{i} 4 \mathrm{p} 108}$

Table 1

BPR Non-Performing Loan

\begin{tabular}{|c|c|c|c|c|c|}
\hline \multirow[t]{2}{*}{ No. } & \multirow[t]{2}{*}{ Bank Name } & \multicolumn{3}{|c|}{$\begin{array}{c}\text { NPL (Non } \\
\text { Performing Loans) }\end{array}$} & \multirow[t]{2}{*}{ Average } \\
\hline & & 2015 & 2016 & 2017 & \\
\hline 1 & PT. BPR Nusamba Tegalalang & 0.01 & 0.02 & 0.04 & 0.02 \\
\hline 2 & PT. BPR Krisna Yuna Dana & 0.02 & 0.07 & 0.16 & 0.08 \\
\hline 3 & PT. BPR Sadhu Artha & 0.02 & 0.03 & 0.03 & 0.03 \\
\hline 4 & PT. BPR Puskusa Balidwipa & 0.07 & 0.11 & 0.12 & 0.10 \\
\hline 5 & PT. BPR Sari Werdhi Sedana & 0.03 & 0.05 & 0.03 & 0.04 \\
\hline 6 & PT. BPR Sukawati Pancanti & 0.02 & 0.04 & 0.05 & 0.04 \\
\hline 7 & PT. BPR Suadana & 0.06 & 0.04 & 0.09 & 0.06 \\
\hline 8 & PT. BPR Artha Bali Jaya & 0.01 & 0.03 & 0.04 & 0.03 \\
\hline 9 & PT. BPR Tish & 0.04 & 0.05 & 0.06 & 0.05 \\
\hline 10 & PT. BPR Bali Dewata & 0.02 & 0.02 & 0.02 & 0.02 \\
\hline 11 & PT. BPR Bank Kertiawan & 0.00 & 0.03 & 0.02 & 0.02 \\
\hline 12 & PT. BPR Suarjaya Ubud & 0.03 & 0.07 & 0.16 & 0.09 \\
\hline 13 & PT. BPR Ulatidana Rahayu & 0.02 & 0.04 & 0.05 & 0.04 \\
\hline 14 & PT. Dragon BPR & 0.02 & 0.08 & 0.02 & 0.04 \\
\hline 15 & PT. BPR Baskara Dewata & 0.00 & 0.06 & 0.08 & 0.05 \\
\hline 16 & PT. BPR Mas Giri Wangi & 0.00 & 0.02 & 0.04 & 0.02 \\
\hline 17 & PT. BPR Aruna Nirmala ambassador & 0.00 & 0.00 & 0.02 & 0.01 \\
\hline 18 & PT. BPR Gianyar Parthasedana & 0,02 & 0.05 & 0.04 & 0.04 \\
\hline 19 & PT. BPR Mitra Bali Srisedana Mandiri & 0.04 & 0.04 & 0.04 & 0.04 \\
\hline 20 & PT. BPR Angga Sedana Yoga & 0.15 & 0.17 & 0.21 & 0.18 \\
\hline 21 & PT. BPR Mulia Wacana & 0.01 & 0.02 & 0.02 & 0.02 \\
\hline 22 & PT. BPR Pertiwi & 0.01 & 0.17 & 0.03 & 0.07 \\
\hline 23 & PT. BPR Raga Jayatama & 0.00 & 0.00 & 0.00 & 0.00 \\
\hline 24 & PT. BPR Dewata Candra Dana & 0.01 & 0.04 & 0.11 & 0.05 \\
\hline 25 & PT. BPR Eka Ayu Artha Bhuwana & 0.05 & 0.08 & 0.13 & 0.09 \\
\hline
\end{tabular}


DOI: $\underline{10.51386 / 25815946 / \mathrm{ijsms}-\mathrm{v} 4 \mathrm{i} 4 \mathrm{p} 108}$

Volume: 4 Issue: 4

Based on Table 1, it can be conveyed that as many as 6 BPRs experienced NPLs above 5 percent, 20 BPRs with NPLs of 0 to 5 percent. This information shows that the BPR still has to make continuous efforts to reduce the level of NPL, as well as the relevant agencies to increase the role of guidance and supervision to create a healthy Rural Bank to support economic growth. Based on the number of loans granted in 2018 - 2019 there were 8 BPRs or 32 percent that experienced a decrease in the number of loans and 17 or 68 percent an increase in the number of loans granted.

Table 2

Amount of Credit Disbursed by BPR in Gianyar Regency (In Thousands of Rupiah)

\begin{tabular}{|c|c|c|c|c|}
\hline \multirow[t]{2}{*}{ No. } & \multirow[t]{2}{*}{ BPR } & \multicolumn{2}{|c|}{ Credits Granted } & \multirow[t]{2}{*}{ ChangeIn $\%$} \\
\hline & & 2018 & 2019 & \\
\hline 1 & PD BPR Werdhi Sedana & $69,322.256$ & $82,621,512$ & 19.18 \\
\hline 2 & PT. BPR Nusamba Tegallalang & $51,387,048$ & $52,604,599$ & 2.37 \\
\hline 3 & PT. BPR Krisna Yuna Dana & $37,141,413$ & $39,059,602$ & 5.16 \\
\hline 4 & PT. BPR Sadhu Artha & $27,408,034$ & $30,851,965$ & 12.57 \\
\hline 5 & PT. BPR Purkusa Bali Dwipa & $14,398,167$ & $13,923,561$ & -3.30 \\
\hline 6 & PT. BPR Sari Werdhi Sedana & $54,471,624$ & $59,744,768$ & 9.68 \\
\hline 7 & PT. BPR. Sukawati Pancakarti & $316,345.824$ & $282,951,580$ & -10.56 \\
\hline 8 & PT. Private BPR & $18,404,244$ & $19,777,275$ & 7.46 \\
\hline 9 & PT. BPR Artha Bali Jaya & $103.766,077$ & 113.5455 .612 & 9.42 \\
\hline 10 & PT. BPR Tish & 70.090 .126 & $53,280,151$ & -23.98 \\
\hline 11 & PT. BPR Bali Dewata & $60,073,499$ & $108,292,862$ & 80.27 \\
\hline 12 & PT. BPR Surya Jaya Ubud & $60,427,025$ & $43,813,252$ & -27.49 \\
\hline 13 & PT. BPR Ulatidana Rahayu & $47,350,108$ & $50,452,010$ & 6.55 \\
\hline 14 & PT. Dragon BPR & $70,475,489$ & $77,741,697$ & 10.31 \\
\hline 15 & PT. BPR Baskara Dewata & $14,351,915$ & $16,570,071$ & 15.46 \\
\hline 16 & PT. BPR Mas Giri Wangi & 902,500 & 456,000 & -49.47 \\
\hline 17 & PT. BPR Aruna Nirmala Duta & $139,457,715$ & $176,374,852$ & 26.47 \\
\hline 18 & PT. BPR Gianyar Parta Sedana & $65,231,873$ & $68,892,781$ & 5.61 \\
\hline 19 & PT. BPR Mitra Bali Sri Sedana & $15,983,951$ & $18,588,481$ & 16.29 \\
\hline 20 & PT. BPR Goose Sedana Yoga & $38,214,182$ & $35,217,713$ & -7.84 \\
\hline 21 & PT. BPR Mulia Wacana & $40,794,945$ & $44,243.996$ & 8.45 \\
\hline 22 & PT. BPR Sarpana Dhana & $7,353,220$ & $5,954,461$ & -19.02 \\
\hline 23 & PT. BPR Raga Jaya Tama & $12,570,294$ & $14,424,342$ & 14.75 \\
\hline 24 & PT. BPR Dewata Candra Dana & 143.519 .585 & $130,396,023$ & -9.14 \\
\hline 25 & PT. BPR Eka Ayu Arta Bhuwana & $59,663,798$ & 73.523832 & 23.23 \\
\hline
\end{tabular}

\section{PROBLEM FORMULATION}

Based on the background that has been described, the formulation of the problem in this study is "How is the soundness of an individual bank using a risk approach (Risk-Based Bank Rating) is a comprehensive and structured assessment of performance results with an assessment coverage of factors namely Risk Profile (Risk Profile), Corporate Governance (GCG), Earning (Rentability), and Capital (Capital) in Gianyar Regency, Bali Province.

\section{III.LITERTAURE REVIEW}

\section{Definition of Bank}

Banks are defined as financial institutions whose business activities are to collect funds from the public and channel these funds back to the public and provide other banking services.[1]. BPR is a bank that specifically serves small communities in sub-districts and villages. The BPR came from the Village Bank, Market Bank, Lumbung Desa, Employee Bank and other banks which were later merged into Rural Banks. The types of products offered by BPRs are relatively narrow when compared to commercial banks, and there are even several types of bank services that BPRs may not provide, such as opening a checking account and participating in clearing. Rural Banks (BPR) are banks that carry out business activities conventionally or based on sharia principles. In its activities it does not provide services in payment traffic based on RI Law no. 10 of 1998 concerning Banking[4].[5][6] 
DOI: $\underline{10.51386 / 25815946 / \mathrm{ijsms}-\mathrm{v} 4 \mathrm{i} 4 \mathrm{p} 108}$

Volume: 4 Issue: 4

July to August 2021

https://www.ijsmsjournal.org

\section{Financial statements}

Financial statement are reports that show the company financial condition at this time or in a certain period. The purpose of financial statement that show the current condition of the company is the current condition. The current condition of the company is the financial condition of the company on a certain date (for the balance sheet) and a certain period (for the income statement). Usually financial reports are made per period, for example three months, or six months, for the company's internal epentingan. ([7][8][9]

\section{Bank Health}

Based on the Financial Services Authority Regulation No. 4/POJK.03/2016, Bank Health which is a reflection of the condition and performance of the bank is a means for the supervisory authority in determining the strategy and focus of supervision of the Bank[3]. In 2011, BI issued a regulation that regulates the rating system for bank soundness, namely PBI No. 13/1/PBI/2011 concerning the assessment of the soundness of commercial banks replacing PBI No. 6/10/PBI/2004[10]. Based on PBI No. 6/10/PBI/2004, the assessment of the soundness of commercial banks is carried out using six assessment factors, namely Capital, Asset, Management, Earning, Liquidity, and Sensitivity to Market Risk, which is abbreviated as CAMELS. Meanwhile, based on PBI No. 13/1/PBI/2011 the assessment of the soundness of banks using the Risk-Based Bank Rating (RBBR) method with four factors, namely Risk Profile (Risk Profile), Corporate Governance (GCG), Profitability (Earnings), and Capital (Capital).

\section{Risk-Based Bank Rating (RBBR) Method}

1. Risk Profile

The risk profile is an overall picture of the risks inherent in bank operations. Banks need to compile a risk profile report. The assessment of risk profile factors is an assessment of the inherent risk and quality of risk management implementation in bank operational activities. The mandatory risk consists of 8 (eight) types of risk according to the Indonesian Bankers Association (2016), namely: credit risk, market risk, operational risk, liquidity risk, legal risk, strategic risk, compliance risk, and reputation risk.[11]

2. Earnings (Profitability) According to[9][12]Profitability (earnings) is a tool to measure the ability of banks to generate profits by comparing profits with assets or capital within a certain period. Profitability also shows how the company's management is responsible for the capital handed over by the capital owner to him, this is indicated by the amount of dividends.

3. Capital (Capital)

Assessment of the capital factor includes an assessment of the level of capital adequacy and capital management. Minimum Capital Adequacy Requirement (CAR) is used in measuring the adequacy of capital owned by banks. The minimum CAR that must be owned by a bank is $12 \%$ of the total risk-weighted assets (RWA).

\section{RESEARCH METHODS}

\section{Data Types and Sources}

The type of research used in this research is descriptive research with a quantitative approach. Descriptive research with a quantitative approach is research that uses data in the form of numbers which are then analyzed to produce information that can describe and interpret the object under study. The data source comes from the financial reports of Rural Banks (BPR) published by the Financial Services Authority (OJK) and scientific journals. References to the study of literature were obtained through previous research journals.

\section{Place and time of research}

The place of this research is in Gianyar district with data collection through BPR financial reports published by Bank Indonesia. The data studied are the years 2015 to 2020.

\section{Research focus}

The focus in this study consists of factors of Risk Profile (Risk Profile), Good Corporate Governance (GCG), Earning (Rentability) and Capital Capital.

Bank Soundness Level Analysis

1. Risk Profile Analysis (Risk Profile) 
DOI: $\underline{10.51386 / 25815946 / \mathrm{ijsms}-\mathrm{v} 4 \mathrm{i} 4 \mathrm{p} 108}$

Volume: 4 Issue: 4

Credit risk is measured by Non-performing Loan (NPL)

NPL $=$ Non-performing Loans/Total Credit $\times 100 \%$

2. Liquidity risk is measured by Loan to Deposit Ratio (LDR)

LDR $=$ Credit/Third Party Funds $x$ 100\%

3. Good Corvorate Governance (GCG) Analysis

The calculation of the Reference Ratio for the study of literature is obtained through the reference of the study of literature. GCG analysis in this research is focused on internal audit and external audit.

4. Earnings Analysis (Profitability)

The profitability ratio used in this study is Return On Assets.

ROA $=$ Net Profit Before Tax / Total Assets x 100\%

5. Capital Analysis (Capital)

Minimum Capital Requirement $(\mathrm{KPMM})=12 \% \mathrm{x}$ RWA

\section{RESULT AND DISCUSSION}

Table 3

Credit Risk with Non Performing Loan (NPL) Ratio 2015-2017

\begin{tabular}{|c|c|c|c|c|c|c|c|}
\hline \multirow{2}{*}{ No } & \multirow{2}{*}{ Name of Rural Bank } & \multicolumn{2}{|r|}{2015} & \multicolumn{2}{|c|}{2016} & \multicolumn{2}{|c|}{2017} \\
\hline & & $\begin{array}{l}\text { NPL } \\
(\%)\end{array}$ & Predicate & $\begin{array}{l}\text { NPL } \\
(\%)\end{array}$ & Predicate & $\begin{array}{c}\text { NPL } \\
(\%)\end{array}$ & Predicate \\
\hline 1 & PT. BPR Nusamba Tegalalang & $1 \%$ & Very healthy & $2 \%$ & Healthy & $4 \%$ & Healthy \\
\hline 2 & PT. BPR Krisna Yuna Dana & $2 \%$ & Healthy & $7 \%$ & Unwell & $16 \%$ & Not healthy \\
\hline 3 & PT. BPR Sadhu Artha & $2 \%$ & Healthy & $3 \%$ & Healthy & $3 \%$ & Healthy \\
\hline 4 & PT. BPR Puskusa Balidwipa & $7 \%$ & Unwell & $11 \%$ & Not healthy & $12 \%$ & Not healthy \\
\hline 5 & PT. BPR Sari Werdhi Sedana & $3 \%$ & Healthy & $5 \%$ & Healthy & $3 \%$ & Healthy \\
\hline 6 & PT. BPR Sukawati Pancanti & $2 \%$ & Healthy & $4 \%$ & Healthy & $5 \%$ & Healthy \\
\hline 7 & PT. BPR Suadana & $6 \%$ & $\begin{array}{c}\text { EnoughHealth } \\
\mathrm{y}\end{array}$ & $4 \%$ & Healthy & $9 \%$ & Unwell \\
\hline 8 & PT. BPR Artha Bali Jaya & $1 \%$ & Very healthy & $3 \%$ & Healthy & $4 \%$ & Healthy \\
\hline 9 & PT. BPR Tish & $4 \%$ & Healthy & $5 \%$ & Healthy & $6 \%$ & $\begin{array}{l}\text { Healthy } \\
\text { enough }\end{array}$ \\
\hline 10 & PT. BPR Bali Dewata & $2 \%$ & Healthy & $2 \%$ & Healthy & $2 \%$ & Healthy \\
\hline 11 & PT. BPR Bank Kertiawan & $0 \%$ & Very healthy & $3 \%$ & Healthy & $2 \%$ & Healthy \\
\hline 12 & PT. BPR Suarjaya Ubud & $3 \%$ & Healthy & $7 \%$ & Unwell & $16 \%$ & Not healthy \\
\hline
\end{tabular}


DOI: $\underline{10.51386 / 25815946 / \mathrm{ijsms}-\mathrm{v} 4 \mathrm{i} 4 \mathrm{p} 108}$

\begin{tabular}{|c|c|c|c|c|c|c|c|}
\hline 13 & PT. BPR Ulatidana Rahayu & $2 \%$ & Healthy & $4 \%$ & Healthy & $5 \%$ & Healthy \\
\hline 14 & PT. Dragon BPR & $0 \%$ & Very healthy & $8 \%$ & Unwell & $2 \%$ & Healthy \\
\hline 15 & PT. BPR Baskara Dewata & $0 \%$ & Very healthy & $6 \%$ & $\begin{array}{l}\text { Healthy } \\
\text { enough }\end{array}$ & $8 \%$ & Unwell \\
\hline 16 & PT. BPR Mas Giri Wangi & $0 \%$ & Very healthy & $2 \%$ & Healthy & $4 \%$ & Healthy \\
\hline 17 & PT. BPR Aruna Nirmaladuta & $0 \%$ & Very healthy & $0 \%$ & $\begin{array}{c}\text { Very } \\
\text { healthy }\end{array}$ & $2 \%$ & Healthy \\
\hline 18 & PT. BPR Gianyar Parthasedana & $2 \%$ & Healthy & $5 \%$ & Healthy & $4 \%$ & Healthy \\
\hline 19 & PT. BPR Mitra Bali Srisedana Mandiri & $4 \%$ & Healthy & $4 \%$ & Healthy & $4 \%$ & Healthy \\
\hline 20 & PT. BPR Angga Sedana Yoga & $15 \%$ & Not healthy & $17 \%$ & Not healthy & $20 \%$ & Not healthy \\
\hline 21 & PT. BPR Mulia Wacana & $1 \%$ & Very healthy & $2 \%$ & Healthy & $2 \%$ & Healthy \\
\hline 22 & PT. BPR Pratiwi & $1 \%$ & Very healthy & $17 \%$ & Not healthy & $3 \%$ & Healthy \\
\hline 23 & PT. BPR Raga Jayatama & $1 \%$ & Very healthy & $16 \%$ & $\begin{array}{c}\text { Very } \\
\text { healthy }\end{array}$ & $4 \%$ & Healthy \\
\hline 24 & PT. BPR Dewata Candra Dana & $1 \%$ & Very healthy & $4 \%$ & Healthy & $11 \%$ & Not healthy \\
\hline 25 & PT. BPR Eka Ayu Artha Bhuwana & $5 \%$ & Healthy & $8 \%$ & Unwell & $14 \%$ & Not healthy \\
\hline
\end{tabular}

Table 4

Credit Risk with Non Performing Loan (NPL) Ratio 2018-2020

\begin{tabular}{|c|c|c|c|c|c|c|c|}
\hline \multirow{2}{*}{ No } & \multirow{2}{*}{ Name of Rural Bank } & \multicolumn{2}{|c|}{2018} & \multicolumn{2}{|c|}{2019} & \multicolumn{2}{|c|}{2020} \\
\hline & & $\begin{array}{l}\text { NPL } \\
(\%)\end{array}$ & Predicate & $\begin{array}{c}\text { NPL } \\
(\%)\end{array}$ & Predicate & $\begin{array}{l}\text { NPL } \\
(\%)\end{array}$ & Predicate \\
\hline 1 & PT. BPR Nusamba Tegalalang & $9 \%$ & Unwell & $9 \%$ & Unwell & $7 \%$ & Unwell \\
\hline 2 & PT. BPR Krisna Yuna Dana & $14 \%$ & Not healthy & $14 \%$ & $\begin{array}{c}\text { Not } \\
\text { healthy }\end{array}$ & $20 \%$ & $\begin{array}{c}\text { Not } \\
\text { healthy }\end{array}$ \\
\hline
\end{tabular}


DOI: $\underline{10.51386 / 25815946 / \mathrm{ijsms}-\mathrm{v} 4 \mathrm{i} 4 \mathrm{p} 108}$

Volume: 4 Issue: 4

\begin{tabular}{|c|c|c|c|c|c|c|c|}
\hline 3 & PT. BPR Sadhu Artha & $3 \%$ & Healthy & $3 \%$ & Healthy & $4 \%$ & Healthy \\
\hline 4 & PT. BPR Puskusa Balidwipa & $14 \%$ & Not healthy & $14 \%$ & Not healthy & $10 \%$ & $\begin{array}{c}\text { Not } \\
\text { healthy }\end{array}$ \\
\hline 5 & PT. BPR Sari Werdhi Sedana & $6 \%$ & $\begin{array}{l}\text { Healthy } \\
\text { enough }\end{array}$ & $6 \%$ & $\begin{array}{l}\text { Healthy } \\
\text { enough }\end{array}$ & $5 \%$ & Healthy \\
\hline 6 & PT. BPR Sukawati Pancanti & $7 \%$ & Unwell & $7 \%$ & Unwell & $6 \%$ & $\begin{array}{l}\text { Healthy } \\
\text { enough }\end{array}$ \\
\hline 7 & PT. BPR Suadana & $7 \%$ & Unwell & $7 \%$ & Unwell & $8 \%$ & Unwell \\
\hline 8 & PT. BPR Artha Bali Jaya & $32 \%$ & Not healthy & $32 \%$ & $\begin{array}{c}\text { Not } \\
\text { healthy }\end{array}$ & $3 \%$ & Healthy \\
\hline 9 & PT. BPR Tish & $17 \%$ & Not healthy & $17 \%$ & $\begin{array}{c}\text { Not } \\
\text { healthy }\end{array}$ & $20 \%$ & $\begin{array}{c}\text { Not } \\
\text { healthy }\end{array}$ \\
\hline 10 & PT. BPR Bali Dewata & $2 \%$ & Healthy & $2 \%$ & Healthy & $4 \%$ & Healthy \\
\hline 11 & PT. BPR Bank Kertiawan & $4 \%$ & Healthy & $4 \%$ & Healthy & $5 \%$ & Healthy \\
\hline 12 & PT. BPR Suarjaya Ubud & $20 \%$ & Not healthy & $20 \%$ & $\begin{array}{c}\text { Not } \\
\text { healthy }\end{array}$ & $13 \%$ & $\begin{array}{c}\text { Not } \\
\text { healthy }\end{array}$ \\
\hline 13 & PT. BPR Ulatidana Rahayu & $5 \%$ & Healthy & $5 \%$ & Healthy & $4 \%$ & Healthy \\
\hline 14 & PT. Dragon BPR & $8 \%$ & Unwell & $8 \%$ & Unwell & $14 \%$ & $\begin{array}{c}\text { Not } \\
\text { healthy }\end{array}$ \\
\hline 15 & PT. BPR Baskara Dewata & $16 \%$ & Not healthy & $16 \%$ & $\begin{array}{c}\text { Not } \\
\text { healthy }\end{array}$ & $6 \%$ & $\begin{array}{l}\text { Healthy } \\
\text { enough }\end{array}$ \\
\hline 16 & PT. BPR Mas Giri Wangi & $4 \%$ & Healthy & $1 \%$ & $\begin{array}{c}\text { Very } \\
\text { healthy }\end{array}$ & $1 \%$ & $\begin{array}{c}\text { Very } \\
\text { healthy }\end{array}$ \\
\hline 17 & PT. BPR Aruna Nirmaladuta & $1 \%$ & $\begin{array}{l}\text { Very } \\
\text { healthy }\end{array}$ & $1 \%$ & $\begin{array}{c}\text { Very } \\
\text { healthy }\end{array}$ & $4 \%$ & Healthy \\
\hline 18 & PT. BPR Gianyar Parthasedana & $11 \%$ & Not healthy & $11 \%$ & $\begin{array}{c}\text { Not } \\
\text { healthy }\end{array}$ & $11 \%$ & $\begin{array}{c}\text { Not } \\
\text { healthy }\end{array}$ \\
\hline 19 & PT. BPR Mitra Bali Srisedana Mandiri & $3 \%$ & Healthy & $3 \%$ & Healthy & $5 \%$ & Healthy \\
\hline 20 & PT. BPR Angga Sedana Yoga & $20 \%$ & Not healthy & $20 \%$ & $\begin{array}{c}\text { Not } \\
\text { healthy }\end{array}$ & $20 \%$ & $\begin{array}{c}\text { Not } \\
\text { healthy }\end{array}$ \\
\hline 21 & PT. BPR Mulia Wacana & $2 \%$ & Healthy & $2 \%$ & Healthy & $2 \%$ & Healthy \\
\hline
\end{tabular}


DOI: $\underline{10.51386 / 25815946 / \mathrm{ijsms}-\mathrm{v} 4 \mathrm{i} 4 \mathrm{p} 108}$

Volume: 4 Issue: 4

July to August 2021

https://www.ijsmsjournal.org

\begin{tabular}{|c|l|c|c|c|c|c|c|}
\hline 22 & PT. BPR Pratiwi & $9 \%$ & Unwell & $9 \%$ & $\begin{array}{c}\text { Not } \\
\text { healthy }\end{array}$ & $3 \%$ & Healthy \\
\hline 23 & PT. BPR Raga Jayatama & $0 \%$ & $\begin{array}{c}\text { Very } \\
\text { healthy }\end{array}$ & $0 \%$ & $\begin{array}{c}\text { Very } \\
\text { healthy }\end{array}$ & $2 \%$ & Healthy \\
\hline 24 & PT. BPR Dewata Candra Dana & 20 & Not healthy & 20 & $\begin{array}{c}\text { Not } \\
\text { healthy }\end{array}$ & 19 & $\begin{array}{c}\text { Not } \\
\text { healthy }\end{array}$ \\
\hline 25 & PT. BPR Eka Ayu Artha Bhuwana & $14 \%$ & Not healthy & $14 \%$ & $\begin{array}{c}\text { Not } \\
\text { healthy }\end{array}$ & $9 \%$ & Unwell \\
\hline
\end{tabular}

The level of Liquidity Risk in 2015 was assessed from the NPL Ratio obtained as many as 11 BPR or 44\% with a very healthy predicate, with an NPL of $0 \%$ and $1 \%$, then there were 11 banks with a healthy predicate or $44 \%$. BPR with the predicate quite healthy with NPL of $6 \%$, as much as one or $4 \%$, namely PT. BPR Suadana, one less healthy BPR namely PT. BPR. Bali Puskusa, and one unhealthy BPR, with 15\% NPL. Results of Liquidity Risk Assessment with Ratio (LDR) at BPR in Gianyar Regency

BPR with very Healthy predicate seen from the NPL of 0 or $1 \%$, among others; Nusamba Tegalalang, BPR Arta Bali Jaya, Kertiawan, Naga, Baskara Dewata, Mas Giri Wangi, Aruna Nirmala Duta, Mulia Discourse, Motherland, Raga Jaya Tama, Dewata Candra Dana. BPR Angga Sedana Yoga, predicate unhealthy, NPL of 15\%.BPR with unhealthy predicate in 2016 increased to 3, namely Angga Sedana Yoga with an NPL ratio of $17 \%$, Puskusa Balidwipa at $11 \%$ and Pertwi at $17 \%$.

The results of the 2019 liquidity assessment are three or 12\% very healthy BPRs, namely Mas Giri Wangi, Nirmala Dewata, Raga Jayatama, 11 or $44 \%$ healthy. BPr with predicate quite healthy as much as 1 or 45 , unhealthy as much as four or $16 \%$, and predicate unhealthy as much as 11 , or $44 \%$.

Based on table 4, it can be explained that in 2020 BPR with the predicate of very healthy as much as 1 or 4 percent, healthy 44 percent, quite healthy 8 percent, less healthy 12 percent and unhealthy 32 percent. Rural Banks with an unhealthy predicate assessing the liquidity risk of the loans, namely; Krisna Yuna Dana, Puskusa Bali Dwipa, Tish, Suarjaya Ubud, Naga, Gianyar Parthasedana, Angga Sedana Yoga and Dewata Candra Dana.

The results of the liquidity assessment with LDR at BPRs in Gianyar Regency The LDR ratio of $80 \%$ is considered healthy, the LDR ratio of $81 \%$ to 99 is considered quite healthy, the ratio $99 \%$ is considered unhealthy. 12 or 48 percent are considered quite healthy. In 2017, BPRs with the predicate of very healthy were 7 or 28 percent, healthy as many as 9 or 36 percent and quite healthy as much as 9 or 36 percent. In 2018, BPRs with very healthy predicates were 8 or 32 percent, healthy were 7 or 28 percent, and quite healthy 10 or 40 percent. In 2019 the results of the LDR Ratio assessment are very healthy as much as 10 or 40 percent, healthy as much as 7 or 28 percent and quite healthy 8 or 32 percent.

The assessment of the Good Corporate Governance (GCG) factor in this study focused on the compliance function with the implementation of internal audit and external audit on financial statements implemented by banks. The internal audit function has been implemented by banks from 2015 to 2020. External audits were implemented by banks in 2019 and 2020. In 2019, 19 or 76 percent of 25 banks were audited by external auditors, and 6 banks or 24 percent were not audited by external auditors, namely Krisna Yuna Dana, Goose Sedana Yoga, Mulia Wacana, Baskara Dewata, Mother Earth and Dewata Candra Dana. In 2020, there were 14 banks that implemented an external audit or 56 percent and 11 banks that did not conduct an external audit or 24 percent.

In 2015, the results of the Profitability Assessment with ROA Ratio were found, all BPRs were very healthy, 2016 BPR Pertiwi were not healthy, 2017 Pertiwi, Suarjaya Ubud and Naga, 2018 Suarjaya Ubud and Pertiwi, 2019 Pertiwi, Candra Dana and Suarjaya Ubud Unhealthy predicate, in 2020 there are 7 unhealthy predicate including Suarjaya Ubud, Naga, Angga Sedana Yoga, Pertiwi, Raga Jayatama and Dewata Candra Dana. 
DOI: $\underline{10.51386 / 25815946 / \mathrm{ijsms}-\mathrm{v} 4 \mathrm{i} 4 \mathrm{p} 108}$

Volume: 4 Issue: 4

July to August 2021

https://www.ijjsmsjournal.org

healthy, among others, the highest supervision of Rural Banks to create a healthy bank to support development. The assessment of the Minimum Capital Adequacy Requirement (KPMM) for the 2015-2020 period was obtained by all BPRs in a very healthy condition with a fulfilment ratio greater than 12 percent

\section{Conclussion}

The results of the Liquidity Risk Assessment, namely credit risk with a Non Performing Loan Ratio (NPL) in 2015, BPRs with the predicate of very healthy as much as 44 percent, healthy 44 percent, quite healthy, unhealthy and unhealthy each at 1 percent. In 2016 BPR with the predicate very healthy 4 percent, healthy 64 percent, quite healthy 4 percent, less healthy 16 percent and unhealthy 12 percent. In 2017, BPR with the predicate very healthy 4 percent, healthy 60 percent, quite healthy 4 percent, less healthy 8 percent and unhealthy 24 percent. In 2018 BPR with the predicate of very healthy as much as 8 percent, healthy 28 percent, quite healthy 4 percent, less healthy 20 percent and unhealthy 40 percent. In 2019 BPR with the predicate very healthy at 12 percent, healthy 24 percent, quite healthy 4 percent, less healthy 16 percent. In 2020 BPR with the predicate very healthy as much as 4 percent, healthy 44 percent, quite healthy 8 percent, less healthy 12 percent and unhealthy 32 percent. The LDR ratio of $80 \%$ is considered healthy, the LDR ratio of $81 \%$ to 99 is considered quite healthy, the ratio $99 \%$ is considered unhealthy. In 2015 there were 13 BPRs with healthy predicates, and 12 BPRs were considered quite healthy.

In 2017 BPR with very healthy predicate as much as 7 or $28 \%$, healthy as much as 9 or $36 \%$ and quite healthy as much as 9 or $36 \%$. In 2018 there were 8 BPRs with very healthy predicates, 7 healthy predicates, and 10 fairly healthy. In 2019 the results of the LDR Ratio assessment were 10 very healthy, 7 healthy and quite healthy 8.

The assessment of the Good Corporate Governance (GCG) factor in this study focused on the compliance function with the implementation of internal audit and external audit on financial statements implemented by banks. The internal audit function has been implemented by banks from 2015 to 2020 . External audits were implemented by banks in 2019 and 2020. In 2019, 19 or 76 percent of 25 banks were audited by external auditors, and 6 banks or 24 percent were not audited by external auditors.

In 2015, the results of the Profitability Assessment with ROA Ratio were found, all BPRs were very healthy, 2016 BPR Pertiwi were not healthy, 2017 Pertiwi, Suarjaya Ubud and Naga, 2018 Suarjaya Ubud and Pertiwi, 2019 Pertiwi, Candra Dana and Suarjaya Ubud Unhealthy predicate, in 2020 there are 7 unhealthy predicate including Suarjaya Ubud, Naga, Angga Sedana Yoga, Pertiwi, Raga Jayatama and Dewata Candra Dana. healthy, among others, the highest supervision of Rural Banks to create a healthy bank to support development.

The assessment of the Minimum Capital Adequacy Requirement (KPMM) for the 2015-2020 period was obtained by all BPRs in a very healthy condition with a fulfilment ratio greater than 12 percent

\section{REFERENCES}

[1] Kasmir, Bank dan Lembaga Keuangan Lainnya. Edisi Revisi, vol. 478, no. July. 2014.

[2] E. D. Pertiwi and Z. Arifin, Analisa pengaruh intellectual capital terhadap kesehatan bank umum yang terdaftar di bursa efek Indonesia, vol. 1. 2017.

[3] "Peraturan Otoritas Jasa Keuangan Nomor 4 /Pojk.03/2016," Otoritas Jasa Keuangan, 2016. https://www.ojk.go.id/id/kanal/perbankan/regulasi/peraturan-ojk/Documents/Pages/pojk-tentang-penilaian-tingkat-kesehatan-bankumum/Salinan-POJK 4 Penilaian.pdf.

[4] "Undang-Undang Republik Indonesia Nomor 10 Tahun 1998," Badan Pembinaan Hukum Nasional, 1998. https://www.bphn.go.id/data/documents/98uu010.pdf.

[5] F. Fauziah, Kesehatan Bank, Kebijakan Dividen dan Nilai Perusahaan: Teori dan Kajian Empiris. 2017.

[6] F. J. Christian, P. Tommy, and J. Tulung, "Analisa Kesehatan Bank Dengan Menggunakan Metode RGEC pada Bank BRI dan Mandiri Periode 2012-2015,” J. EMBA, vol. 5, no. 2, 2017.

[7] Kasmir, “Analisis Rasio Keuangan,” J. Chem. Inf. Model., 2019. 
DOI: $\underline{10.51386 / 25815946 / \mathrm{ijsms}-\mathrm{v} 4 \mathrm{i} 4 \mathrm{p} 108}$

Volume: 4 Issue: 4

July to August 2021

https://www.ijjsmsjournal.org

[8] A. S. Irfani, Manajemen Keuangan dan Bisnis: Teori dan Aplikasi. 2020.

[9] Suyono, Manajemen keuangan, konsep dan aplikasi. 2019.

[10] "Peraturan Bank Indonesia Nomor: 13/ 1 /Pbi/2011," Otoritas Jasa Keuangan, 2011. https://www.ojk.go.id/id/kanal/perbankan/regulasi/peraturan-bank-indonesia/Documents/96.pdf.

[11] Ikatan Bankir Indonesia, Manajemen Kesehatan Bank Berbasis Risiko. Jakarta, 2016.

[12] A. A. Putri, S. Asmapane, and ..., "Pengaruh risiko risk based bank rating dalam memprediksi indikasi financial distress pada perusahaan perbankan di bursa efek indonesia," Jurnal. Ilmu Akuntansi, 2020. 